\title{
A VIEW AS TO THE PROFILE OF A LAWYER IN PRIVATE PRACTICE
}

\section{ALAN D. HUNTER, Q.C.}

This article presents a view of the qualifications a lawyer in private practice ought to possess, based on the experiences that the author has had in his years in practice and as a Bencher of the Law Society of Alberta. He lists the professional and personal characteristics that the public should expect from a lawyer.
L'auteur du présent article présente les qualifications que serait censé posséder un avocat en pratique privée, d'après ses expériences en tant que membre du conseil de la Law Society of Alberta. Il énumère les caractéristiques professionnelles et personnelles que le public est en droit d'attendre des membres du barreau.

In preparation for participating in the workshop, "Ethics and the Workplace" at the National Conference on the Legal Profession and Ethics, I gave some consideration to what qualifications a lawyer in private practice ought to possess based on my practice experience and my years as a Bencher of the Law Society of Alberta.

The following represents what, in my view, are the requisite characteristics and which may have aided the discussions at the workshop and may indeed be useful in other forums. I start with the premise that the practice of law is a state-permitted monopoly and thus the public is entitled to have certain expectations of a lawyer in private practice. It is my view that the public has a right to expect that such a lawyer will possess the following professional and personal characteristics:

(1) A thorough understanding of the law.

(2) A recognition that the law is not immutable and that there is a need to have a continuing interest in changes in the law (indeed the lawyer should continue to be a student of the law).

(3) A demonstrated analytical ability.

(4) Demonstrated written and oral communication skills.

(5) Conscientiousness and a good understanding of human nature.

(6) A strong interest in problem solving before there is a problem, in risk aversion and risk minimization, and after there is a problem, in dispute resolution.

(7) A good imagination for creative solutions.

(8) Wisdom.

(9) Good judgment.

(10) Diligence.

(11) Efficiency.

(12) Competence.

(13) Honesty.

(14) Candour.

(15) Discretion.

(16) Care and prudence.

(17) Fearlessness.

(18) That he or she is a person of the utmost integrity. 
The characteristic of integrity should be taken as encompassing qualities of trustworthiness and honourableness. In short, the lawyer should be trustworthy and honourable in dealing with his or her colleagues, the client, the courts and those engaged in the administration of justice. Furthermore, the lawyer should conduct himself or herself at all times with courtesy and in good faith.

All of the foregoing engage notions of diligence and dedication and these notions involve the risk that the private practice of law can become an all-consuming commitment, giving rise to the need to achieve a balance between one's personal and professional lives. There are many practice delivery choices available to a qualified lawyer that offer the prospect of a less demanding level of professional commitment, but do not involve any sacrifice of the essential characteristics. For instance, in private practice one may practice alone, in association with others, as an associate or as a partner with other like-minded individuals. As well, the practice may be general or limited to specific areas.

It must also be recognized that the private practice of law is not immune from economic realities. Business efficiencies become of greater importance in difficult economic times. Cost cutting and more efficient delivery of legal services become the operative paradigm. All this is taking place at a time when the consumer of legal services is becoming increasingly sophisticated in legal matters and the matters themselves are increasingly complex. The future is now for those considering the practice of law in private practice. However, one must remember what the qualifications are and the high degree of dedication and commitment that is required. 